\title{
The Readiness of Elementary School Teachers to Implemented the Independent Learning Policy in Determining Student Graduation in the Kuningan Sub- District
}

\author{
Ndaru Mukti Oktaviani' ${ }^{1}$, Isnaini Wulandari ${ }^{2}$, Arrofa Acesta ${ }^{3}$, Rini Ramdhania ${ }^{4}$, Slamet \\ Arifin 5 \\ Elementary School Teacher Training, Faculty of Teacher Training and Education, Kuningan University \\ \{ndaru.mukti.oktaviani@uniku.ac.id'1, isnaini.wulandari@uniku.ac.id², arrofa.acesta@uniku.ac.id², \\ rini.ramdhania@uniku.ac.id ${ }^{4}$, slamet.arifin@uniku.ac.id ${ }^{5}$ \}
}

\begin{abstract}
The aim of the research is to analyze the readiness of elementary school teachers to implementing the independent learning policy on determining student graduation in the Kuningan Sub-District. The type of research used is quantitative research with the research method of survey research. The research subject was 6-grade elementary school teachers in Kuningan Sub-District. Data collected by questionnaires and interviews. The survey approach used in this study refers to the survey research steps proposed by Rea and Parker. The sampling technique used purposive random sampling. The results showed the percentage of the emotive-attitudinal sub variable had the highest percentage of $79.88 \%$, the cognitive readiness sub variable was $76.34 \%$, and the behavioral readiness sub variable had a percentage of $80.23 \%$. The overall percentage of the three sub-variables on the readiness of elementary school teachers is in the "very ready" category with a percentage of $78.82 \%$. The results of this research illustrate that elementary school teachers, especially grade 6 teachers in Kuningan Sub-District are very ready to implement government policies in terms of independent learn about determining student graduation. It is shown that 6-grade elementary school teachers can be responsive to any policy changes that occur and quickly adjust to being part of the improvement of education quality
\end{abstract}

Keywords: The Readiness; Elementary school teacher; independent learning; Kuningan Sub-District

\section{Introduction}

Life in the 21 st century brings changes that occur quickly and are not easily predictable. This, of course, requires every individual to have comprehensive skills, both hard skills and soft skills to be able to live to compete in the national and global arena. Three skills must be mastered by humans: 1 . learning and innovation skills, 2 . information, media, and technology skills, 3. life and career skills (Trilling \& Fadel, 2009). Fulfillment of all the skills needed to be prepared as early as possible to form high quality human and able to face the challenges of the times. The process will be effective when taken through education. Education is believed to be one of the areas that have an important and strategic role in the development of a nation ( (Ningrum, 2009). Therefore, the government should continuously improve the quality of education through curriculum reform. As it is known, the curriculum is the soul of education 
(the heart of education), so that quality education can be achieved through developing the right curriculum (Oktaviani \& Wulandari, 2019). One part of the curriculum that is used to prove curriculum achievement is the competency standards of graduates.

Graduate competency standards are competency standards that must be mastered by every student after they have completed a level of education. To measure the achievement of graduate competency standards, school exams are carried out. The current implementation of school exams has changed following the latest regulations listed in the Freedom of Learning Policy in determining student graduation. The Independent Learning Policy in determining student graduation contains student graduation is carried out through school exams held by each education unit and school exam materials are prepared by the teacher in each educational unit. However, it should be remembered that if the education unit is unable to compile the test materials independently, it is permissible to use test materials from various other sources, starting from the MGMP (Subject Teacher Conference) and the KKG (Teacher Working Group). This of course presents new challenges for every teacher, especially in the ability to develop exam materials. Therefore, this policy must be immediately socialized to education implementers in the field, especially teachers, to ensure the readiness of teachers in implementing the policy.

Each individual must have sufficient readiness to complete each task in the job, as well as for a teacher. The readiness of a teacher has an important role in ensuring the quality of an educational process. This is because the teacher is the main subject in carrying out the learning process (Oktaviani \& Wulandari, 2019). For a teacher, readiness is not only to the skill but also to the technique of instruction (Jansen, 1969). Further, readiness can be classified into three parts (Maddox, Forte, \& Boozer, 2000), namely Emotive Attitudinal Readiness or attitude and emotional readiness consisting of: a. Emotional readiness is assumed as the responsibility to perform a task, b. Enthusiasm for a task, c. Ability to adapt to tasks at any time, d. Comfort and independence in carrying out duties, e. Appreciate the intrinsic value in a task; Cognitive Readiness or cognitive readiness consists of a. Have cognitive skills and critical thinking that are important to do their job, b. Aware of strengths and weaknesses, $c$. It is easy to make a connection between the task at hand and the reality on the ground, d. Aware of self-worth and willingness to carry out duties, e. Able to integrate concepts and tools from various scientific disciplines; and Behavioral Readiness or readiness of behavior consists of: a. Willing to carry out a partnership function with their colleagues and facilitators, b. Adept at managing time to achieve goals that match their duties.

As we all know, the readiness of teachers has an important role in the successful implementation of policies. This is because each policy has a direct impact on the main implementer in the field, namely teachers (Oktaviani \& Wulandari, 2019). Likewise, the policy of independent learning in determining student graduation. Teachers are required to be cognitive, affective, and psychomotor ready to carry out these policies. However, in reality, it is not yet known to what extent the readiness of teachers in implementing the independent learning policy in determining student graduation. For this reason, this study comes intending to further analyze the readiness of elementary school teachers to implement the independent learning policy in determining student graduation, especially in Kuningan District, Kuningan Regency, West Java. 


\section{Method}

This research is a survey research type with a quantitative descriptive approach (Creswell, 2014). This survey research refers to the survey research steps proposed by Rea and Parker in (Sukmadinata, 2010) follows: a. identification of the focus of the study and method of research; b. the research schedule and budget; c. establishment of an information-based; $d$. the sampling frame; d. determination of sample size and sample selection; e. design of the survey instrument; f. pretest of survey instrument; g. selection and training interview; $h$. implementation of the survey; i. codification of the completed questionnaires and computerized data entry; and j. data analysis and final report. To facilitate research, researchers compile a chart of research implementation as follows:

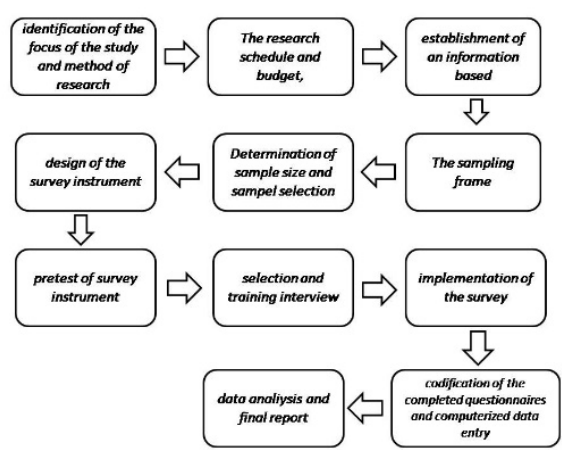

Fig 1. The chart of the Rea and Parker's Survey Research Implementation

This research was conducted in SD Negeri / equivalent in Kuningan Sub-District, West Java with the research time being March-November 2020. The population is all elements that will be described by a writer in writing, this is reinforced by Sugiyono's statement (Sugiyono, 2016) which gives the understanding that population is a generalization area consisting of objects or subjects that become certain quantities and characteristics set by the author for the study and then conclude. The research implementation of teacher readiness for the implementation of school exams was carried out with 43 teachers as respondents (sample). The number of respondents was taken from the total teacher population of 110 teachers. The population of this study was a grade 6 elementary school teacher in Kuningan District and the research sample was determined by purposive random sampling. The data collection techniques used in the study were questionnaires and interviews. This questionnaire is used to collect data on the readiness of teachers to implement the independent learning policy in determining student graduation.

The questionnaire is a data collection tool used to collect data by making a list of questions, this is in line with Anggoro's (Anggoro, 2009) questions which suggests that a questionnaire called a data collection tool generally consists of a series of questions or written questions used to collect information research desired. This is in line with Trianto's opinion (Trianto, 2010) that a questionnaire is data collection, the form of a questionnaire sheet can be in the form of several written questions, the aim of which is to obtain information from respondents about what they have experienced and know. The following is a grid of elementary school teacher readiness instruments to implement the independent learning policy in determining student graduation: 
Table 1. Elementary School Teacher Readiness Questionnaire Grid to Implement the Independent Learning Policy in Determining Student Graduation

\begin{tabular}{|c|c|c|c|c|c|}
\hline \multirow[t]{2}{*}{ No } & \multirow{2}{*}{$\begin{array}{c}\text { Sub } \\
\text { Variable }\end{array}$} & \multirow[t]{2}{*}{ Indicator } & \multicolumn{2}{|c|}{ Item } & \multirow{2}{*}{$\begin{array}{l}\text { Number } \\
\text { of Items }\end{array}$} \\
\hline & & & $\begin{array}{c}\text { Positive } \\
(+)\end{array}$ & $\frac{\text { Negative }}{(-)}$ & \\
\hline \multirow[t]{5}{*}{1.} & \multirow{5}{*}{$\begin{array}{l}\text { Emotive- } \\
\text { Attitudinal }\end{array}$} & 1.1 Responsible & 1,2 & & 2 \\
\hline & & 1.2 Enthusiastic & 3 & & 1 \\
\hline & & 1.3 Adaptability & 4 & & 1 \\
\hline & & 1.4 Independence & 5 & & 1 \\
\hline & & $\begin{array}{l}1.5 \text { Appreciate the intrinsic } \\
\text { value in a task }\end{array}$ & 6 & & 1 \\
\hline \multirow[t]{5}{*}{2.} & \multirow{5}{*}{$\begin{array}{l}\text { Cognitive } \\
\text { Readiness }\end{array}$} & 2.1 Critical thinking & 7 & & 1 \\
\hline & & $\begin{array}{l}2.2 \text { Be aware of the advantages } \\
\text { and disadvantages }\end{array}$ & 8,9 & & 2 \\
\hline & & 2.3 Think contextually & 10 & & 1 \\
\hline & & $2.4 \mathrm{Be}$ aware of self-worth & 11 & & 1 \\
\hline & & $\begin{array}{l}2.5 \text { Able to integrate various } \\
\text { scientific disciplines }\end{array}$ & 12 & & 1 \\
\hline \multirow[t]{2}{*}{3.} & \multirow[t]{2}{*}{$\begin{array}{l}\text { Behavioral } \\
\text { Readiness }\end{array}$} & $\begin{array}{l}3.1 \text { Carry out a partnership } \\
\text { function }\end{array}$ & 13,14 & & 2 \\
\hline & & 3.2 Good at managing time & 15 & & 1 \\
\hline \multicolumn{5}{|c|}{ Total } & 15 \\
\hline
\end{tabular}

Regarding questionnaires compiled and distributed through the google form platform, considering that Indonesia is currently experiencing a Covid-19 pandemic so that a possible step to collect data is through e-questionnaires because it does not require face-to-face contact. The following is a picture of part of the questionnaire that the researcher gave to the respondent.

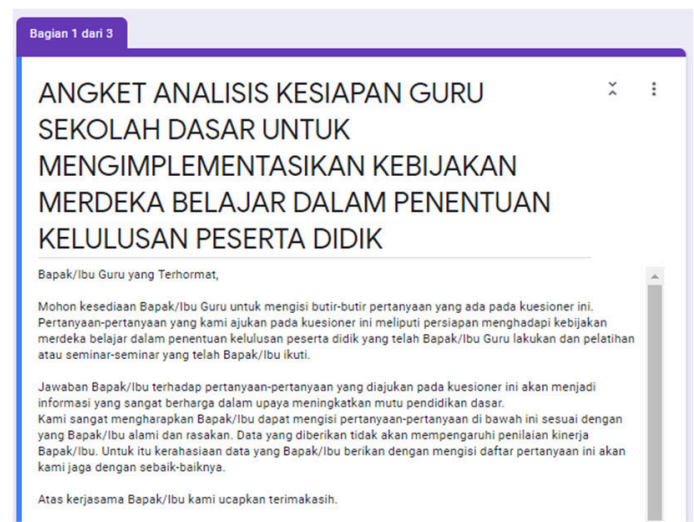

Fig 2. Part of The Questionnaire (Google Form) To Retrieve the Data of Respondents

The next instrument is an interview. The interviews conducted in this research used an unstructured interview type to make it easier for researchers to collect data according to the information provided by the research subjects. The following guidelines researchers used interviews to interview respondents:

Table 2. Interview Guidelines

\begin{tabular}{|c|c|c|}
\hline No & Sub Variable & Indicator \\
\hline \multirow[t]{5}{*}{1.} & \multirow{5}{*}{$\begin{array}{l}\text { Emotive- } \\
\text { Attitudinal }\end{array}$} & 1.1 Responsible \\
\hline & & 1.2 Enthusiastic \\
\hline & & 1.3 Adaptability \\
\hline & & 1.4 Independence \\
\hline & & 1.5 Appreciate the intrinsic value in a task \\
\hline \multirow[t]{4}{*}{2.} & \multirow{4}{*}{$\begin{array}{l}\text { Cognitive } \\
\text { Readiness }\end{array}$} & 2.1 Critical thinking \\
\hline & & $2.2 \mathrm{Be}$ aware of the advantages and disadvantages \\
\hline & & 2.3 Think contextually \\
\hline & & $2.5 \mathrm{Be}$ aware of self-worth \\
\hline \multirow[t]{2}{*}{3.} & \multirow{2}{*}{$\begin{array}{l}\text { Behavioral } \\
\text { Readiness }\end{array}$} & $\begin{array}{l}\text { 2.5 Able to integrate various scientific disciplines } \\
3.1 \text { Carry out a partnership function }\end{array}$ \\
\hline & & 3.2 Good at managing time \\
\hline
\end{tabular}


The data analysis technique used in this paper is a descriptive analysis. In this writing, the analysis of quantitative data obtained from the answers to the questionnaire is by separating the data into similar parts, as well as looking for the average value and percentage of respondents' answers. The results obtained are interpreted in the percentage of qualitative sentences:

Table 3. Qualitative Interpretation of Percentages

\begin{tabular}{|l|l|}
\hline \multicolumn{1}{|c|}{ Percentage } & \multicolumn{1}{c|}{ Category } \\
\hline $76 \%<x \leq 100 \%$ & Very ready \\
\hline $51 \%<x \leq 76 \%$ & Ready \\
\hline $26 \%<x \leq 51 \%$ & Less Ready \\
\hline $0 \% \leq x \leq 26 \%$ & Not ready \\
\hline
\end{tabular}

\section{Result and Discussion}

Research on the readiness of elementary school teachers to implement the independent learning policy in determining student graduation using a closed questionnaire obtained the following results.

\subsection{Overall elementary school teacher readiness}

The following is the percentage of each sub variable of overall teacher readiness.

Table 4. Percentage of each Sub-Variable Elementary School Teacher Readiness

\begin{tabular}{|l|c|c|c|}
\hline \multicolumn{1}{|c|}{ Sub Yariabel } & Score & Percentage & Category \\
\hline $\begin{array}{l}\text { Sub Yariabel Emotive- } \\
\text { Attitudinal }\end{array}$ & 818 & 79,88 & Very Ready \\
\hline $\begin{array}{l}\text { Sub Variabel Cognitive } \\
\text { Readiness }\end{array}$ & 778 & 76,34 & Very Ready \\
\hline $\begin{array}{l}\text { Sub Variabel Behavioral } \\
\text { Readiness }\end{array}$ & 413 & 80,23 & Very Ready \\
\hline Total & $\mathbf{2 0 0 9}$ & $\mathbf{7 8 , 8 2}$ & Very Ready \\
\hline
\end{tabular}

Based on the table, the percentage results for Emotive-Attitudinal Sub Variables were $79.88 \%$ with the very ready category, $76.34 \%$ Cognitive Readiness Sub Variables with the very ready category, and $80.23 \%$ Behavioral Readiness Sub Variables with the very ready category.

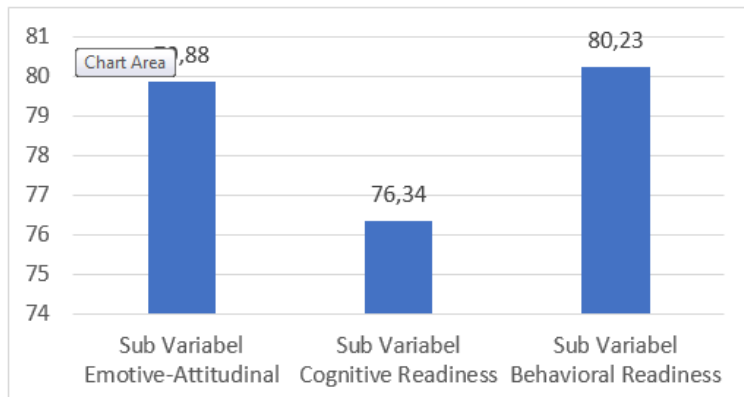

Fig 3. Teacher Readiness Diagram to Implement the Independent of Learning Policy in Determining Student Graduation in Kuningan Sub-District 
Based on the data in the table, the results show that the overall percentage of the teacher readiness variable is $78.82 \%$, this percentage shows that the overall readiness of elementary school teachers in implementing learning independence is classified in the Very Ready category. The following is the percentage of elementary school teachers' readiness to implement the independent learning policy in determining student graduation in Kuningan District in the form of a diagram.

\subsection{Percentage of each sub variable teacher readiness}

The following is the percentage of teacher readiness to implement the independent learning policy in determining student graduation in Kuningan District for each sub-variable. The subvariables referred to are emotive attitudinal, cognitive readiness, and behavioral readiness. Starting with the first sub variable, the emotive attitudinal readiness sub variable which can be seen from the data results in the following table:

Table 5. Percentage of Sub Variable Emotive Attitudinal

\begin{tabular}{|l|c|c|c|}
\hline \multicolumn{1}{|c|}{ Indicator } & Score & Percentage & Category \\
\hline Responsible & 262 & 76,16 & Very Ready \\
\hline Enthusiastic & 133 & 77,33 & Very Ready \\
\hline Adaptability & 131 & 76,16 & Very Ready \\
\hline Independence & 152 & 88,37 & Very Ready \\
\hline $\begin{array}{l}\text { Appreciate the } \\
\text { intrinsic value in a } \\
\text { task }\end{array}$ & 140 & 81,4 & Very Ready \\
\hline \multicolumn{1}{|c|}{ Total } & $\mathbf{8 1 8}$ & 79,88 & Very Ready \\
\hline
\end{tabular}

Based on the table above, the percentage of teacher readiness on the Emotive Attitudinal sub-variable in Kuningan District consists of several indicators, namely $76.16 \%$ responsible, $77.33 \%$ enthusiastic, $76.16 \%$ adaptability, independence, the percentage of numbers $88.37 \%$, and the last indicator, namely appreciate the intrinsic value in a task, the amount is $81.4 \%$. This indicates that the readiness of the teacher for the attitudinal emotive variable is at $79.88 \%$. For more details, the readiness of elementary school teachers on the emotive attitudinal variable can be seen in Figure 4 below:

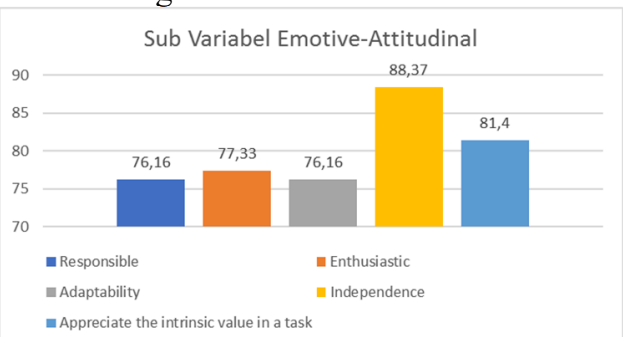

Fig 4. Percentage Diagram of Teacher Readiness in Emotive Attitudinal Sub-Variables Furthermore, the second sub variable is cognitive readiness. The following is a detailed description of the indicators and the percentage of the cognitive readiness sub-variables:

Table 6. Percentage of Sub Variable Cognitive Readiness

\begin{tabular}{|l|c|c|c|}
\hline \multicolumn{1}{|c|}{ Indicator } & Score & Percentage & Category \\
\hline Critical thinking & 130 & 75,58 & Very Ready \\
\hline $\begin{array}{l}\text { Be aware of the } \\
\text { advantages and } \\
\text { disadvantages }\end{array}$ & 243 & 70,64 & Very Ready \\
\hline Think contextually & 123 & 71,51 & Very Ready \\
\hline $\begin{array}{l}\text { Be aware of self- } \\
\text { worth }\end{array}$ & 163 & 94,8 & Very Ready \\
\hline $\begin{array}{l}\text { Able to integrate } \\
\text { various scientific } \\
\text { disciplines }\end{array}$ & 119 & 69,19 & Ready \\
\hline \multicolumn{1}{|c|}{ Total } & $\mathbf{7 7 8}$ & $\mathbf{7 6 , 3 4}$ & Very Ready \\
\hline
\end{tabular}


Based on the table above, the percentage of teacher readiness in the sub-variable cognitive readiness in Kuningan District consists of several indicators, namely Critical thinking of $75.58 \%$, be aware of the advantages and disadvantages of $70.64 \%$, think contextually of 71 , $51 \%$, be aware of the percentage of self-worth at $94.8 \%$, and the last indicator, namely able to integrate various scientific disciplines, is $69.19 \%$. This indicates that the readiness of teachers at sub-variables of cognitive readiness stands at $76.34 \%$ categorized as very ready. For more details on the readiness of elementary school teachers in the cognitive readiness sub variable in Kuningan Sub-District, it can be seen in Figure 5 below:

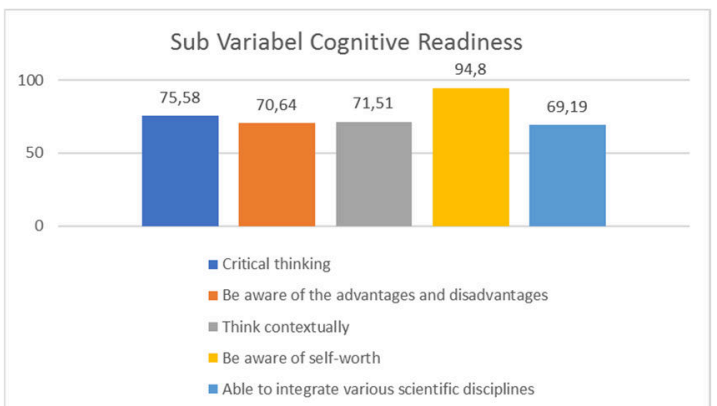

Fig 5. Percentage Diagram of Teacher Readiness in Sub-Variable Cognitive Readiness

The third sub variable of the elementary school teacher's readiness variable, namely the sub variable behavioral readiness. The following provides a breakdown of the indicators and the percentage of the Behavioral Readiness sub-variables:

Table 7. The Percentage of Sub Variable Behavioral Readiness

\begin{tabular}{|c|c|c|c|}
\hline Indicator & Score & Percentage & Category \\
\hline $\begin{array}{l}\text { Carry out a } \\
\text { partnership function }\end{array}$ & 274 & 79,65 & Very Ready \\
\hline $\begin{array}{l}\text { Good at managing } \\
\text { time }\end{array}$ & 139 & 80,81 & Very Ready \\
\hline Total & 413 & 80,23 & Very Ready \\
\hline
\end{tabular}

Based on the table above, the percentage of teacher readiness in the sub-variable behavioral readiness in Kuningan Sub-District consists of several indicators, namely the Carry out a partnership function of $79.65 \%$, and the second indicator good at managing the time of $80.81 \%$. This indicates that the readiness of the teacher in the behavioral readiness sub variable is at $80.23 \%$ in the very ready category. For more details on the readiness of primary school teachers on the behavioral readiness sub variable can be seen in Figure 6 below:

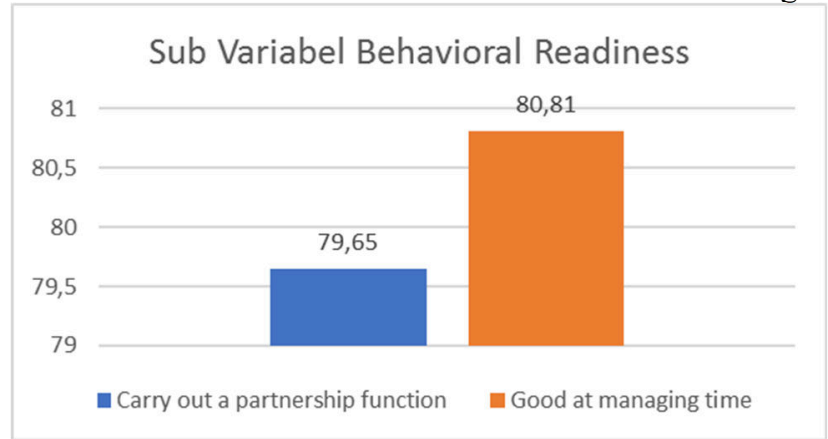

Fig 6. Percentage Diagram of Teacher Readiness in Sub-Variable Cognitive Readiness 
When viewed quantitatively, from the results of the data above, the readiness of elementary school teachers to implement the independent learning policy set by the government is very ready. As is well known, in 2020 the Ministry of Education and Culture issued Circular Letter Number I of 2020 concerning the Policy of Independent Learning in Determining Student Graduation (Kemendikbud, 2020) this policy contains procedures for determining student graduation. The policy above is actually not much different from the Regulation of the Minister of Education and Culture Number 43 of 2019 concerning the Implementation of Examinations which are held by the Education Unit and the National Examination on the form side of the exam. However, the form of examination contained in Permendikbud No. 43 of 2019 (Kemendikbud, 2019) is intended for semester examinations. Meanwhile, the latest policy is aimed at school exams.

School/madrasah exams are activities carried out to measure the achievement of student competencies as recognition of learning achievement and/or completion of an educational unit (Permendikbud No. 23/2016). Basically, the school exam is a "national exam" at the elementary school level, but in the process of its implementation, the ministry of education and culture is only related to the preparation of rules and the preparation of $25 \%$ of the Bahasa, mathematics, and natural science, while other processes are submitted to the education office province and district/city (Pakpahan, 2015). Seeing the position of school exams in measuring the achievement of Graduates' Competency Standards, the government always pays special attention to the implementation process. If there is serious attention from the government regarding this policy if it needs to be balanced with the readiness of teachers in facing or implementing the policy in the field. Therefore, research on the readiness of teachers to implement these policies is needed. Following are the results of a survey conducted by researchers in Kuningan Sub-District, Kuningan District for grade 6 elementary school teachers.

Research on the readiness of elementary school teachers was carried out by focusing on three sub-variables, namely the emotive attitudinal readiness, cognitive readiness, and behavioral readiness sub-variables. Each sub variable has indicators as a form of specific description. The research results regarding the indicators of each variable are described as follows. The emotive attitudinal readiness sub variable consists of five indicators, namely responsible, enthusiastic, adaptability, independence, and an indicator of appreciating the intrinsic value in a task. Each indicator has a percentage of different respondents' answers. The highest score was achieved in the independence indicator at $88.37 \%$. On the other hand, two indicators have the lowest percentage of figures but the numbers are the same, namely responsible and adaptability. Both have a percentage of $76.16 \%$. Responsible and adaptability indicators are very well prepared, however, the percentage is the smallest among the other indicators. This means that the percentage of indicators of responsibility and willingness to adapt to primary school teachers is not too high, it is at the lower limit of the very ready category.

This shows that grade 6 elementary school teachers feel that there is still something blocking in implementing their learning media policy. This can be seen from the results of the interview, as follows: "Have you heard and been told, but there is no practical direction for implementing the policy, still waiting for instructions from the office or superiors." (YH Interview, 19 October 2020). The results of the interview suggest that there is still confusion in implementing the independent learning policy in determining student graduation because teachers do not know the practice of implementing the policy, so the responsible and 
adaptability of the teacher seems not yet fully ready because it has not been directed by superiors/offices to adapt immediately in practice with the policy.

This is in line with what was stated by the Ministry of Education and Culture (Kemendikbud, Ujian Nasional Diganti Asesmen Kompetensi dan Survei Karakter, 2019) that teachers in Indonesia must be able and immediately to adapt to the changing era and adjustments to government policies. Continuing from this, it seems that the independence of the elementary school teachers is very ready. This expression was summarized in the interview with the DJ as follows: "We don't know how to develop test materials including the assessment because we haven't been informed, but at the Teacher Working Group forum we have started discussions to discuss the policy and access documents from the central government." (DJ Interview, 21 October 2020). The results of the interview suggest that the readiness of the primary school teacher independence indicator is classified as high, as evidenced by the results of the survey score of $88,37 \%$ in the very ready category.

Switching to the second sub variable, cognitive readiness. This second sub has five indicators as well as in the first sub variable. The indicators are critical thinking, be aware of the advantages and disadvantages, think contextually, be aware of self-worth, and can integrate various scientific disciplines. There are two interesting phenomena from this sub variable, namely the findings of data from indicators of being aware of self-worth and being able to integrate various scientific disciplines. The first phenomenon is that elementary school teachers in Kuningan Sub-District are very aware of their values. This was revealed from the results of the following interview: "Yes, for the strengths, maybe I still have a lot of time and energy to continue learning the purpose of this program, while my weakness is that I still lack knowledge of this program and the actual learning conditions in the field." (IA interview, 20 October 2020).

The results of the interview showed that the teacher really understood and acknowledged the strengths and weaknesses themselves during the process of implementing the independent learning policy in determining student graduation. This high teacher readiness is indicated by the high percentage of the indicator be aware of self-worth at $94.8 \%$ with the very ready category. The next finding is in this second sub-variable, namely the indicator able to integrate various scientific disciplines. It was found that this indicator has the smallest percentage number among other indicators, even the indicator category is in the "ready" category. This indicates that teachers are not yet very capable of integrating various scientific disciplines. This was revealed by respondents through the following interview results: "I will discuss a lot / look for a lot of information by other teachers / certain sources so that the results can be as expected" (EM Interview, 20 October 2020).

Respondents' answers indicate that the teacher is not fully ready to integrate learning materials, they still need to ask a lot of questions and seek information, but there are efforts to achieve these following applicable policies. The behavioral readiness sub variable is the third sub variable which describes the readiness variable of elementary school teachers to implement the independent learning policy in determining student graduation. Teachers have shown mastery of the carry out a partnership function indicator and good at managing time, which is indicated by the amount for the third sub variable of $80.23 \%$ in the "very ready" category. This can also be seen in the following interview results: "How to carry out the partnership function, yes, I will discuss it with colleagues and discuss it in the teacher working group, if it is not possible to continue asking questions to the supervisor." (LN interview, 22 October 2020). The respondent's answer suggested that the teacher really used or carried out the partnership function well, starting with the closest partner first and then continuing to the 
higher partner, namely the supervisor if it was felt that they needed discussion. The teacher fully understands his position when working in a team and when working individually.

\section{Conclusion}

Based on the results of survey research that has been carried out on the readiness of elementary school teachers to implement the independent learning policy in Kuningan SubDistrict, it can be concluded that:

The percentage of results per sub variable, starting from the Emotive-Attitudinal Sub Variable of $79.88 \%$ with the very ready category, the cognitive readiness sub variable of $76.34 \%$ with the "very ready" category, and the last sub variable, behavioral readiness of $80.23 \%$ fell into the "very ready" category. The overall percentage reached $78.82 \%$ in the "Very Ready" category. This indicates that elementary school teachers in Kuningan SubDistrict, Kuningan District are very ready to implement the independent learning policy, especially in determining the graduation of grade 6 students to continue to the next level of education. To comprehensively determine conditions throughout Kuningan District regarding the readiness of elementary school teachers to implement the policy of independent learning, especially determining student graduation, it is necessary to carry out further research in other sub-districts.

\section{References}

[1] Anggoro, M. T. (2009). Metode Penelitian. Jakarta: Universitas Terbuka Press.

[2] Creswell, J. W. (2014). Research Design Qualitative, Quantitative, and Mixed Methods Approaches. America: SAGE Publications, Inc.

[3] Jansen, A. R. (1969). Understanding Readiness: An Occasional Paper. ERIC, 49-62.

[4] Kemendikbud. (2019). Penyelenggaraan Ujian yang Diselenggarakan Satuan Pendidikan dan Ujian Nasional. Jakarta: Kementerian Pendidikan dan Kebudayaan.

[5] Kemendikbud. (2019). Ujian Nasional Diganti Asesmen Kompetensi dan Survei Karakter. Jakarta: Kemendikbud. Retrieved from https://www.kemdikbud.go.id/main/blog/2019/12/tahun-2021-ujiannasional-diganti-asesmen-kompetensi-dan-survei-karakter

[6] Kemendikbud, K. P. (2020). Kebijakan Merdeka Belajar Dalam Penentuan Kelulusan Peserta Didik dan Pelaksanaan Penerimaan Peserta Didik Baru Tahun Ajaran 2020/2021. Jakarta: Kementerian Pendidikan dan Kebudayaan.

[7] Maddox, N., Forte, M., \& Boozer, R. (2000). Learning Readiness: An Underappreciated Yet Vital Dimension in Experiental Learning. Journal of Developments in Business Simulation \& Experiental Learning, 277-291.

[8] Ningrum, E. (2009). Pengembangan Sumber Daya Manusia Bidang Pendidikan. Geografi Gea, 9(1), 16-28. doi:https://doi.org/10.17509/gea.v9i1.1681 
[9] Oktaviani, N. M., \& Wulandari, I. (2019). Problematika Penerapan Kurikulum 2013 di Sekolah Dasar. Yogyakarta: K-Media.

[10] Pakpahan, R. (2015). Ujian Sekolah sebagai Upaya Pemetaan Mutu Sekolah Dasar. Jurnal Pendidikan dan Kebudayaan, 21(2), 167-181.

[11] Sugiyono. (2016). Metode Penelitian Pendidikan Kuantitatif, Kualitatif, dan R\&D. Bandung: Alfabeta.

[12] Sukmadinata, N. S. (2010). Metode Penelitian Pendidikan. Bandung: Remaja Rosdakarya.

[13] Trianto. (2010). Pengantar Penelitian Pendidikan bagi Pengembangan Profesi Pendidikan \& Tenaga Kependidikan. Jakarta: Kencana Prenada Media Group.

[14] Trilling, B., \& Fadel, C. (2009). 21st Century Skills: Learning for Life in Our Times. San Francisco, CA: John Wiley \& Sons. 